\title{
Sorption of trace metals on calcite: Applicability of the surface precipitation model
}

\author{
ROB N. J. COMANS and JACK J. MIDDELBURG \\ Department of Geochemistry, Institute of Earth Sciences, University of Utrecht, \\ P.O. Box 80.021, 3508 TA Utrecht, The Netherlands
}

(Received March 30, 1987; accepted in revised form July 27, 1987)

\begin{abstract}
Published sorption isotherm data of $\mathrm{Cd}^{2+}, \mathrm{Mn}^{2+}, \mathrm{Zn}^{2+}$, and $\mathrm{Co}^{2+}$ on calcite are adequately described by the surface precipitation model which was originally developed by FARLEY et al. (1985) for the sorption of cations on metal oxides. In addition to monolayer adsorption, the model accounts for the formation of a surface phase with a composition that is described by a solid solution having as end members the sorbent calcium carbonate mineral and a pure carbonate precipitate of the sorbing trace metal. The model thus specifies a continuum between adsorption and precipitation. This feature is supported in the literature by observations on the reaction kinetics and the amount of surface coverage during trace metal sorption on calcite. The apparent adsorption constants of these trace metals, as derived from the model, can be ranked according to the degree to which their ionic radii match the ionic radius of $\mathrm{Ca}^{2+}$.
\end{abstract}

\section{INTRODUCTION}

CALCITE, BEING THE MOST abundant carbonate mineral, occurs in a variety of geochemical environments such as soils and freshwater and marine sediments. Despite its abundance, relatively little is known about its surface chemistry and its interactions with trace metals at the solid/solution interface (MORSE, 1986). Detailed knowledge of these processes may prove very useful because they record the chemical environment in which calcium carbonate has been formed. For instance, the cadmium content of benthic foraminifera has been used by BOYLE (1986) to reconstruct paleophosphate levels and paleo-oceanic circulation. Manganese and zinc have been used successfully as tracers for modelling carbonate diagenesis (PINGITORE, 1978). Furthermore, it has been shown that the aqueous solubility of trace metals can be governed by interaction with carbonate minerals (THOMSON et al., 1986; MIDDELBURG et al., 1987). However, a more fundamental mechanistic approach to interactions between carbonate mineral surfaces and trace metals is clearly required.

SOMASUNDARAN and AGAR (1967) were the first to describe the surface chemistry of calcite in terms of surface complexation reactions. On the basis of thermodynamical calculations on the system calcite/ aqueous solution/atmosphere they suggest that $\mathrm{Ca}^{2+}$, $\mathrm{HCO}_{3}^{-}, \mathrm{CO}_{3}^{2-}, \mathrm{H}^{+}$and $\mathrm{OH}^{-}$are the potential determining ions.

Although many sorption studies have been done with hydrous metal oxides and clay minerals, there have been relatively few experimental studies on the sorption of trace metals on calcite (HEYDEMANN, 1959; MCBRIDE, 1979, 1980; JURINAK and BAUER, 1956; KITANO et al., 1976; FrANKLIN and MORSE, 1982,
1983; KORNICKER et al., 1985). Most of the studies on calcite show remarkable agreement as regards observations on the kinetics of the sorption processes: an initial rapid uptake of the trace metal followed by a period of relatively slow removal from solution. The rapid sorption step is generally ascribed to an adsorption reaction, whereas the slow uptake, at relatively high concentrations, is commonly thought to represent (solid solution) precipitation on the calcite surface. It was also observed by MCBRIDE (1980) and JURINAK and BAUER (1956) that sorption isotherms showed surface saturation followed by increased sorption at higher equilibrium concentrations.

The most direct evidence for initial rapid adsorption and subsequent nucleation and precipitation on the calcite surface at higher concentrations was given by MCBRIDE (1979). From measurements of surface area and unit cell size McBride calculated that the adsorption density of $\mathrm{Mn}^{2+}$ on calcite was higher than could be explained by the number of adsorption sites available. Electron Spin Resonance (ESR) data indicated that no discrete new phase formed at low $\mathrm{Mn}^{2+}$ surface concentrations, but that at high concentrations $\mathrm{MnCO}_{3}$ was nucleated on the calcite surface. It was suggested by MCBRIDE (1979) that the sorption process was continuous from chemisorption to precipitation.

Because sorption data for cations on metal oxides do not show saturation in adsorption density at monolayer surface coverage but show a continuous increase, FARLEY $e t$ al. (1985) postulated that the sorption process could be depicted more accurately by allowing for a continuum between adsorption reactions and precipitation. These authors therefore proposed a model that is conceptually similar to the BET-isotherm which describes a continuum between monolayer gas ad- 
sorption and ultimate condensation of the gas. By analogy, the model accounts for a continuum between adsorption and a precipitation reaction which is described by the formation of a surface phase whose composition varies continuously between that of the original solid and a pure precipitate of the sorbing cation.

The obvious coincidence between the underlying principles of the 'surface precipitation model' of FARLEY et al. (1985) and the experimental observations reported in the literature on the sorption of trace metals on calcite, inspired us to try and apply the model to these data. In this paper we present the results of our modelling efforts on the sorption of $\mathrm{Cd}^{2+}, \mathrm{Mn}^{2+}, \mathrm{Zn}^{2+}$. and $\mathrm{Co}^{2+}$ on calcite, using data of MCBRIDE (1980), MCBRIDE (1979), JURINAK and BAUER (1956). and KORNICKER et al. (1985), respectively.

In a very recent paper, to which our attention was drawn during review, DAvis et al. (1987) propose a mechanism for the sorption of $\mathrm{Cd}$ on calcite, which is supported by a unique combination of $\mathrm{Cd}$ sorption and $\mathrm{Ca}$ isotopic exchange experiments. This two-step mechanism is very similar to the mechanism which forms the basis of the model of FARLEY et al. (1985): the first step involves a fast adsorption reaction followed by diffusion of $\mathrm{Cd}^{2+}$ into a surface layer of hydrated $\mathrm{CaCO}_{3}$ that overlies crystalline calcite. The second step is solid solution formation in new crystalline material which grows from the disordered mixture of $\mathrm{Cd}$ and Ca carbonate in the hydrated surface layer.

\section{FORMULATION OF THE MODEL IN TERMS OF TRACE METAL/CALCTTE INTERACTION}

The concept of the surface precipitation model is discussed in detail by FARLEY et al. (1985) in connection with the sorption properties of cations on metal oxides. If we extend this concept to sorption of cations on carbonates, the sorption process can be summarized briefly as follows (for clarity, we use the term 'adsorption' only for monolayer coverage of the surface, whereas 'sorption' is used to denote all processes that transfer a cation from solution to the solid phase): when a cation adsorbs on the surface of a carbonate mineral. a second carbonate surface is created which permits a further transfer of both the sorbing cation and cations of the sorbent mineral to the solid phase. Therefore, in addition to monolayer adsorption, the model allows for the formation of a surface phase with a composition that is described by a solid solution having as end members the sorbent calcium carbonate mineral and a pure carbonate precipitate of the sorbing cation. An alternative suggestion put forward by DAvIS $e t a l$, (1987) is that the solid solution grows from a disordered mixture of $\mathrm{Cd}$ and $\mathrm{Ca}$ carbonate in a hydrated surface layer that overlies crystalline calcite; the existence of this surface layer was proposed by Muccl et al. (1985). This alternative does not affect the validity of the "surface precipitation model' as formulated here.
In the mathematical model for the surface precipitation concept metals at the carbonate/water interface are treated as surface species, whereas metals which are not in direct contact with the solution, but separated by the adsorption monolayer, are treated as solid species. The surface precipitation reactions for the sorption of trace metals on calcium carbonate can then be wniten as follows:

Adsorption of $\mathrm{M}^{2+}$ on $\mathrm{CaCO}_{3}(\mathrm{~s})$ :

$=\mathrm{CaCO}_{3}^{0}+\mathrm{M}^{2+}+\mathrm{HCO}_{3}^{-\Lambda_{\text {ads }}}=\mathrm{CaCO}_{3}(\mathrm{~s})$

$$
+-\mathrm{MCO}_{+}^{\mathrm{i}}+\mathrm{H}^{+}
$$

Precipitation of $\mathrm{M}^{2+}$

$$
\begin{aligned}
=\mathrm{MCO}_{3}^{0}+\mathrm{M}^{2+}+\mathrm{HCO}_{3}^{-1 / h_{\text {spm }}} & \mathrm{MCO}_{3}(\mathrm{~s}) \\
& +=\mathrm{MCO}_{3}^{4}+\mathrm{H}^{+}
\end{aligned}
$$

Adsorption of $\mathrm{Ca}^{2+}$ on $\mathrm{MCO}_{3}(\mathrm{~s})$ :

$$
\begin{aligned}
=\mathrm{MCO}_{3}^{0}+\mathrm{Ca}^{2+}+\mathrm{HCO}_{3}^{-} \stackrel{\mathrm{s}^{\mathrm{a}}}{=} \mathrm{MCO}_{3}(\mathrm{~s}) \\
+=\mathrm{CaCO}_{3}^{0}+\mathrm{H}^{+}
\end{aligned}
$$

Precipitation of $\mathrm{Ca}^{2+}$ :

$$
\begin{aligned}
=\mathrm{CaCO}_{3}^{0}+\mathrm{Ca}^{2+}+\mathrm{HCO}_{3}^{-1 / k_{\text {spa }}}= & \mathrm{CaCO}_{3}(\mathrm{~s}) \\
& +=\mathrm{CaCO}_{3}^{0}+\mathrm{H}^{+} .
\end{aligned}
$$

The surface symbol = is used here to indicate bonds of the metal at the adsorption monolayer. Since only three of thesc four expressions are independent, $K_{\text {ads }}$ can be written as $1 / K_{\mathrm{ads}} K_{\mathrm{spM}} K_{\mathrm{spCa}}$.

As formulated in Eqn. (1), the mechanism of trace metal adsorption causes some $\mathrm{CaCO}_{3}(\mathrm{~s})$ to dissolve [reverse of Eqn. (4)] in order to neutralize the resulting proton. This approach is in accordance with that of MCBRIDE (1979), who suggested that the release of $\mathrm{Ca}^{2+}$ during adsorption of $\mathrm{Mn}^{2+}$ was not the result of direct ion displacement but was effected by a proton transfer according to Eqns. (1) and (4),

The mole balances for the model can be written as follows:

$$
\begin{aligned}
\text { TOTM } & =\left[\mathrm{M}^{2+}\right]+\left[=\mathrm{MCO}_{3}^{0}\right]+\left[\mathrm{MCO}_{3}(\mathrm{~s})\right] \\
\text { TOTCa } & =\left[\mathrm{Ca}^{2+}\right]+\left[=\mathrm{CaCO}_{3}^{0}\right]+\left[\mathrm{CaCO}_{3}(\mathrm{~s})\right] \\
S_{\mathrm{T}} & =\left[=\mathrm{CaCO}_{3}^{0}\right]+\left[=\mathrm{MCO}_{3}^{0}\right]
\end{aligned}
$$

where $S_{\mathrm{T}}$ represents the total concentration of surface sites for cation binding. For a particular $\mathrm{pH}$ the surface precipitation model can be expressed in the form of a 'BET-like' sorption isotherm (FARLEY et al., 1985):

$$
\begin{gathered}
\begin{array}{c}
(B-1)\left[\mathrm{M}^{2+}\right]\left\{S_{\mathrm{T}} / \mathrm{TOTCa}\left(1-\left[\mathrm{M}^{2+}\right] /\left[\mathrm{M}^{2+}\right]_{s}\right)\right. \\
\left.+\left(1 /(B-1)+\left[\mathrm{M}^{2+}\right] /\left[\mathrm{M}^{2+}\right]_{s}\right)\right\}
\end{array} \\
\left(\left[\mathrm{M}^{2+}\right]_{\mathrm{s}}-\left[\mathrm{M}^{2+}\right]\right)\left\{1+(B-1)\left[\mathrm{M}^{2+}\right] /\left[\mathrm{M}^{2+}\right]_{\mathrm{s}}\right\} \\
\frac{\left[\mathrm{Ca}^{2+}\right]_{\mathrm{s}}\left[\mathrm{M}^{2+}\right]}{\text { TOTCa}\left[\mathrm{M}^{2+}\right]}
\end{gathered}
$$


where $B=K_{\text {ads }} K_{\text {spM }} ;\left[\mathrm{M}^{2+}\right]_{\mathrm{s}}=K_{\mathrm{spM}}\left\{\mathrm{H}^{+}\right\} /\left[\mathrm{HCO}_{3}^{-}\right]$ $=K_{\mathrm{spM}}\left\{\mathrm{H}^{+}\right\}^{2} / K_{1} K_{\mathrm{H}} P_{\mathrm{CO}_{2}} ;\left[\mathrm{Ca}^{2+}\right]_{\mathrm{s}}=K_{\mathrm{spCa}}\left\{\mathrm{H}^{+}\right\} /\left[\mathrm{HCO}_{3}^{-}\right]$ $=K_{\mathrm{spCa}}\left\{\mathrm{H}^{+}\right\}^{2} / K_{1} K_{\mathrm{H}} P_{\mathrm{CO}_{2}}\left(K_{1}, K_{\mathrm{H}}, P_{\mathrm{CO}_{2}}\right.$ are the first acidity constant of the carbonate system, the Henry's law constant of the carbonate system, and the partial pressure of $\mathrm{CO}_{2}$, respectively); and

$$
\Gamma_{\mathrm{M}}=\frac{\left[=\mathrm{MCO}_{3}^{0}\right]+\left[\mathrm{MCO}_{3}(\mathrm{~s})\right]}{\text { TOTCa }}
$$

indicating total moles of $\mathrm{M}^{2+}$ sorbed per mole of total calcium.

\section{APPLICATION OF THE SURFACE} PRECIPITATION MODEL TO ISOTHERM DATA

As was mentioned earlier, we applied the surface precipitation model to published laboratory data on the sorption of $\mathrm{Cd}^{2+}, \mathrm{Mn}^{2+}, \mathrm{Zn}^{2+}$, and $\mathrm{Co}^{2+}$ on calcite (MCBRIDE, 1980; MCBRIDE, 1979; JURINAK and BAUER, 1956; and KORNICKER et al., 1985, respectively). In all of these studies an aqueous phase was used, consisting of the metal chloride solution without further background electrolyte, except for $\mathrm{Zn}^{2+}$ where the ionic strength was kept constant at $0.01 \mathrm{M}$ with $\mathrm{NaCl}$. Equilibration times were $24 \mathrm{hrs}, 24 \mathrm{hrs}, 6 \mathrm{hrs}$, and 3-8 hrs for the isotherm data of $\mathrm{Cd}^{2+}, \mathrm{Mn}^{2+}, \mathrm{Zn}^{2+}$, and $\mathrm{Co}^{2+}$, respectively. It should be noted at this point that the laboratory experiments from which the available sorption data were derived were not designed for modelling purposes. Except for the data on $\mathrm{Mn}^{2+}$ and $\mathrm{Cd}^{2+}$ (MCBRIDE, 1979, 1980), the applied concentration range of the sorbing metal, the type of calcite, the equilibration time, and the values for $\mathrm{pH}$ and TOTCa, are all different for each trace metal. No attempts were made to control the pII. In spite of these restrictions and because of the absence of a more consistent set of data, we feel that the data are adequate for testing the applicability of the surface precipitation model.

We applied the model to the isotherm data using the adsorption constant $\left(K_{\text {ads }}\right)$ and the solubility product of the trace metal carbonate $\left(K_{\mathrm{spM}}\right)$ as fitting parameters. The total number of surface sites available for cation binding ( $S_{\mathrm{T}} /$ TOTCa) was estimated from the double-logarithmic isotherm plots (see FARLEY et al., 1985) and found to be in agreement with the adsorption maxima observed or calculated by MCBRIDE $(1979,1980)$, JURINAK and BAUER (1956) and KORNICKER et al. (1985). A sensitivity analysis showed that the use of different values for $K_{\mathrm{spM}}$ did not affect the optimum isotherm fit in the concentration range where adsorption dominates, and different values for $K_{\text {ads }}$ had no effect on the concentration range of dominant solid solution precipitation. Values for $K_{\mathrm{H}}, K_{1}$, and $P_{\mathrm{CO}_{2}}$ for the carbonate system were taken from STUMM and MORgaN (1981) and for $K_{\text {spCa }}$ from PluMMER and BUSENBERG (1982).

The isotherm fits of the surface precipitation model for the sorption of $\mathrm{Cd}^{2+}, \mathrm{Mn}^{2+}, \mathrm{Zn}^{2+}$, and $\mathrm{Co}^{2+}$ on calcite are shown in Fig. 1. The apparent constants for adsorption and for solid solution precipitation which were used in the model [i.e., in the 'B' term of Eqn. $(8)$ ], the total concentration of surface sites $\left(S_{\mathrm{T}}\right)$, and the TOTCa and $\mathrm{pH}$ values are indicated. For the $\mathrm{Co}^{2+}$ experiments, neither the exact TOTCa value (only the upper and lower limits) nor the $\mathrm{pH}$ was given. We estimated the $\mathrm{pH}$ value to be 8.4 , by assuming equilibrium with calcite and atmospheric $\mathrm{CO}_{2}$. We observed that for the experimental conditions the second term of Eqn. (8) was negligible and that consequently only the $S_{\mathrm{T}}$ /TOTCa ratio was significant. This was verified by model calculations for $\mathrm{Co}^{2+}$ using both the upper and lower limits of the TOTCa values given by KORNICKER et al. (1985). During the calculations, the pH was kept constant at the values listed in Fig. 1, although MCBRIDE $(1979,1980)$ observed a lowering of the $\mathrm{pH}$ at high adsorption density. JURINAK and BAUER (1956) and KORNICKER et al. (1985) did not monitor the $\mathrm{pH}$ during their experiments.

The isotherm fits of the surface precipitation model (Fig. 1) show that the model provides a good description of the sorption process of these four trace metals on calcite, despite the differences in experimental conditions. The apparent adsorption constants of $\mathrm{Cd}^{2+}$, $\mathrm{Mn}^{2+}, \mathrm{Zn}^{2+}$, and $\mathrm{Co}^{2+}\left(10^{1.43}, 10^{0.65}, 10^{0.08}\right.$, and $10^{-0.40}$, respectively) follow the sequence expected from their ionic radii and from the similarity of these radii to the ionic radius of $\mathrm{Ca}^{2+}(r=0.99 \AA): \mathrm{Cd}^{2+}(0.97 \AA)>\mathrm{Mn}^{2+}$ $(0.80 \AA)>\mathrm{Zn}^{2+}(0.74 \AA)>\mathrm{Co}^{2+}(0.72 \AA)$ (WEAST, 1981). It is reasonable to expect that (valences being equal) the affinity of the metal for the calcite surface will increase with the degree to which the ionic radius of the metal matches that of $\mathrm{Ca}^{2+}$. The apparent adsorption constants of $\mathrm{Cd}^{2+}, \mathrm{Mn}^{2+}$, and $\mathrm{Co}^{2+}$ are also consistent with their distribution coefficients in calcite, as determined by LORENS (1981). At the slowest rate of calcite precipitation, during recrystallization (near or at calcite saturation), LORENS (1981) found: $D_{\mathrm{Cd}}$ $\left(10^{1.85}\right)>D_{\mathrm{Mn}}\left(10^{1.71}\right)>D_{\mathrm{Co}}\left(10^{0.92}\right)$. It should be mentioned here that the model assumes sorption under equilibrium conditions with respect to calcite solubility. Otherwise, the incorporation of trace metal into calcite may be controlled by kinetic factors, as was shown by LORENS (1981).

On the basis of the present data, it is not possible to make a valid comparison between the apparent solubility products of the trace metal carbonates (Fig. 1) and literature values. As was stated above, the $\mathrm{pH}$ was not controlled in any of the experimental studies. A change in the $\mathrm{pH}$ is expected whenever the trace metal carbonate-instead of calcite-controls the equilibrium composition of the solution (STUMM and MORGAN, 1981). MCBRIDE (1979, 1980) did indeed observe a $\mathrm{pH}$ decrease at high surface coverage, i.e., during solid solution precipitation. The fact that the $\mathrm{pH}$ was kept constant during the model calculations might thus have influenced the apparent solubility products. Note also that we assumed the formation of an ideal solid solution, whereas the carbonate system under consideration shows non-ideal solid solution behaviour (LIPPMANN, 1980). In the latter situation, $K_{\mathrm{spM}}$ is a 

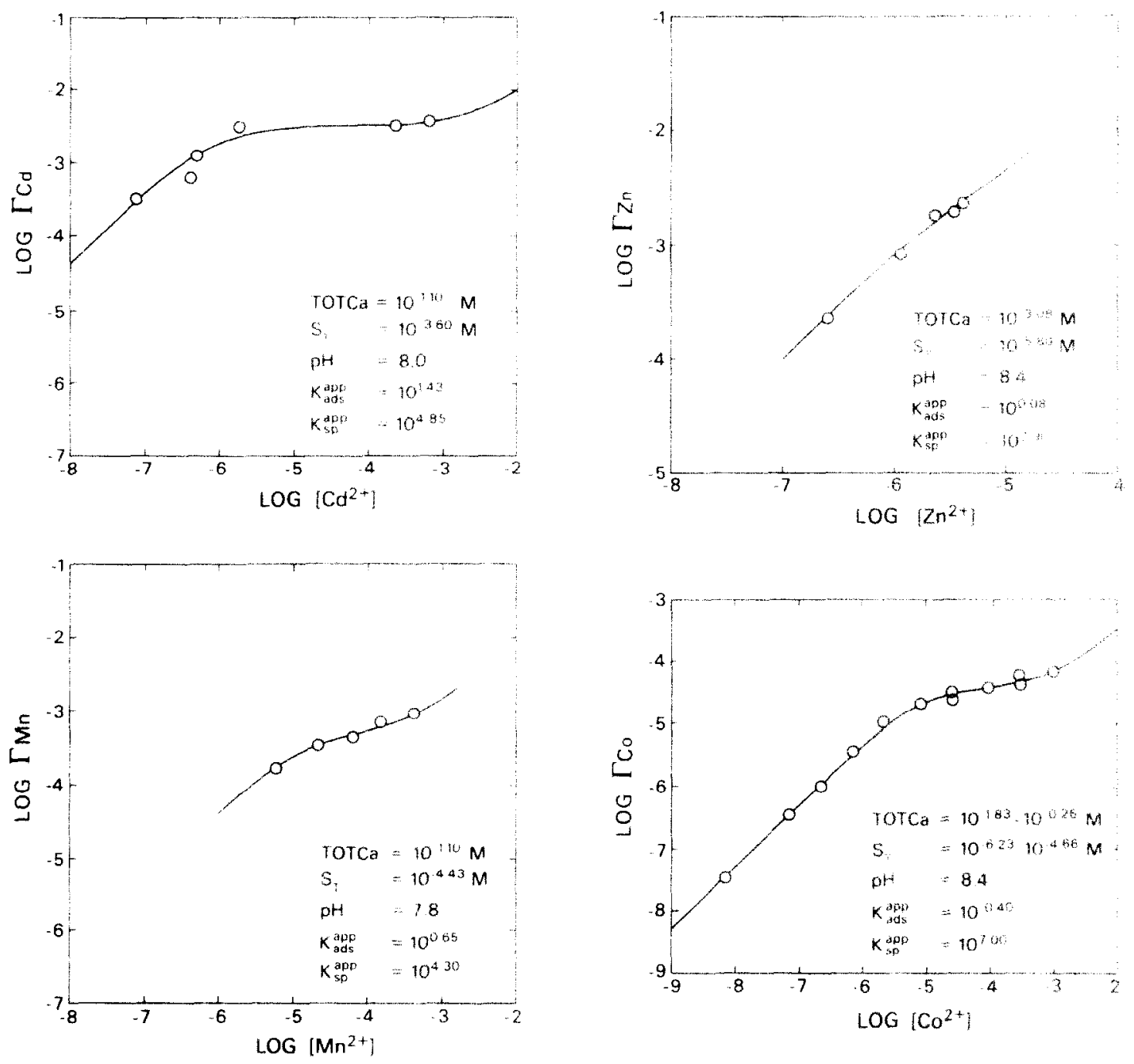

FIG. 1. Isotherm fits of the surface precipitation model for the sorption of $\mathrm{Cd}^{2+}, \mathrm{Mn}^{2+}, \mathrm{Zn}^{2+}$ and $\mathrm{Co}^{2+}$ on calcite. Data from MCBRIDE (1980); MCBRIDE (1979); JURINAK and BAUER (1956) and KORNICKER el af (1985), respectively. $\Gamma_{M}$ indicates total moles of $M^{2+}$ sorbed per mole of total calcium.

function of the trace metal concentration in the solid. This may cause a variation of several orders of mag nitude in $K_{\text {spm }}$ values (MIDDELBURG et al., 1987). Consequently, the solubility products are to be regarded as fitting parameters (FARLEY et al., 1985).

DZOMBAK and MOREL (1986), in a paper subsequent to that of FARLEY et al. (1985), included a second (weaker) binding site in the 'surface precipitation model.' Assuming ideal solid solution behaviour in their hydrous metal oxide system, they were able by means of this extension to use published $K_{\mathrm{spM}}$ values and therefore required no additional fitting parameter. Adequate data concerning trace metal sorption on calcite (especially at high sorbate/sorbent ratios) to test this approach are not available at present. Provided additional data of sufficient quality become available. future modelling efforts might benefit from the inclusion of a second (adsorption) surface site in the "surface precipitation model.'

\section{CONCLUSIONS}

The sorption of $\mathrm{Cd}^{2+}, \mathrm{Mn}^{2+}, \mathrm{Zn}^{2+}$, and $\mathrm{Co}^{2+}$ on cal cite has been shown to be adequately described by the surface precipitation model of FARLEY $a$ al (1985). The underlying principles of the model, which allows for a continuum between adsorption and precipitation. are supported by observations on the reaction kinetics and the amount of surface coverage during trace metal sorption on calcite. The need for such a model was recently expressed by MORSE (1986) after a thorough review of the literature.

The apparent adsorption constants of these trace metals, as derived from the model, can be ranked according to the degree to which their ionic radii match the ionic radius of $\mathrm{Ca}^{2+}$. The available laboratory data which were used to test the applicability of the model do not fully meet the criteria necessary to justify the derivation of more generally valid modelling constants 
for adsorption and solid solution precipitation. There is evidently a need for a consistent set of data on trace metal sorption on carbonate minerals. To obtain these data it will be necessary to do laboratory experiments which include long equilibration times (of the order of days), a wide range of dissolved metal concentrations (up to high sorbate/sorbent ratios) and surface saturations, and in which a constant $\mathrm{pH}$ is maintained throughout the experiments. When used in conjunction with such a consistent data base, from which we can derive constants of more general validity, the surface precipitation model will extend our knowledge of the mechanistics of the interactions between trace metals and carbonate minerals.

Acknowledgements-H. A. Das, H. J. De Baar, G. J. De Lange, and C. H. Van Der Weijden critically read an earlier draft of the manuscript. Miss S. M. McNab is thanked for linguistic advice and $J$. J. van Bergenhenegouwen for making the line drawings. We thank A. Mucci and two anonymous reviewers for examining the manuscript thoroughly and for making constructive remarks. J. A. Davis kindly sent us a preprint of his forthcoming paper.

Editorial handling: S. E. Calvert

\section{REFERENCES}

BOYLE E. A. (1986) Paired carbon isotope and cadmium data from benthic foraminifera: implications for changes in oceanic phosphorus, oceanic circulation, and atmospheric carbon dioxide. Geochim. Cosmochim. Acta 50, 265-276.

Davis J. A., Fuller C. C. and COOK A. D. (1987) A model for trace metal sorption processes at the calcite surface: Adsorption of $\mathrm{Cd}^{2+}$ and subsequent solid solution formation. Geochim. Cosmochim. Acta 51, 1477-1490.

DzombaK D. A. and Morel F. M. M. (1986) Sorption of cadmium on hydrous ferric oxide at high sorbate/sorbent ratios: equilibrium, kinetics, and modeling. J. Colloid Interface Sci. 112, 588-598.

FARLEY K. J., DZOMBAK D. A. and MOREL F. M. M. (1985) A surface precipitation model for the sorption of cations on metal oxides. J. Colloid Interface Sci. 106, 226-242.

FrANKLIN M. L. and MORSE J. W. (1982) The interaction of copper with the surface of calcite. Ocean Sci. Engn. 7, 147174.

FRANKLIN M. L. and MORSE J. W. (1983) The interaction of manganese (II) with the surface of calcite in dilute solutions and seawater. Mar. Chem. 12, 241-254.

HEYDEMANN A. (1959) Adsorption aus sehr verdünnten Kupferlösungen an reinen Tonmineralen. Geochim. Cosmochim. Acta 15, 305-329.

JURINAK J. J and BAUER N. (1956) Thermodynamics of zinc adsorption on calcite, dolomite and magnesite-type minerals. Soil Sci. Soc. Amer. Proc. 20, 466-471.

KITANO Y., KaNAMORI N. and YOSHIOKA S. (1976) Adsorption of zinc and copper ions on calcite and aragonite and its influence on the transformation of aragonite to calcite. Geochem. J. 10, 175-179.

KORNICKer W. A., MORSE J. W. and Damasceno R. N. (1985) The chemistry of $\mathrm{Co}^{2+}$ interaction with calcite and aragonite surfaces. Chem. Geol. 53, 229-236.

LIPPMANN F. (1980) Phase diagrams depicting aqueous solubility of binary mineral systems. Neues Jahrb. Mineral. Abh. 139, 1-25.

LORENS R. B. (1981) Sr, Cd, Mn and Co distribution coefficients in calcite as a function of calcite precipitation rate. Geochim. Cosmochim. Acta 45, 553-561.

MCBRIDE M. B. (1979) Chemisorption and precipitation of $\mathrm{Mn}^{2+}$ at $\mathrm{CaCO}_{3}$ surfaces. Soil Sci. Soc. Amer. J. 43, 693698.

MCBRIDE M. B. (1980) Chemisorption of $\mathrm{Cd}^{2+}$ on calcite surfaces. Soil Sci. Soc. Amer. J. 44, 26-28.

MidDelbuRg J. J., DE LANGE G. J. and VAN DER WEIJDEN C. H. (1987) Manganese solubility control in marine pore waters. Geochim Cosmochim. Acta 51, 759-763.

MORSE J. W. (1986) The surface chemistry of calcium carbonate minerals in natural waters: an overview. Mar. Chem. 20, 91-112.

MUCCl A., MORSE J. W. and KAMINSKI M. S. (1985) Auger spectroscopy analysis of magnesian calcite overgrowths precipitated from seawater and solutions of similar composition. Amer. J. Sci. 285, 289-305.

PINGITORE N. E. (1978) The behaviour of $\mathrm{Zn}^{2+}$ and $\mathrm{Mn}^{2+}$ during carbonate diagenesis: theory and applications. $J$. Sediment. Petrol. 48, 799-814.

Plummer L. N. and Busenberg E. (1982) The solubilities of calcite, aragonite and vaterite in $\mathrm{CO}_{2}-\mathrm{H}_{2} \mathrm{O}$ solutions between 0 and $90^{\circ} \mathrm{C}$ and an evaluation of the aqueous model for the system $\mathrm{CaCO}_{3}-\mathrm{CO}_{2}-\mathrm{H}_{2} \mathrm{O}$. Geochim. Cosmochim. Acta 46, 1011-1040.

SOMASUNDARAN P. and AGAR G. E. (1967) The zero point of charge of calcite. J. Colloid Interface Sci. 24, 433-440.

Stumm W. and Morgan J. J. (1981) Aquatic Chemistry. John Wiley \& Sons, 780p.

Thomson J., Higgs N. C., Jarvis I., Hydes D. J., Colley S. and WILSON T. R.S. (1986) The behaviour of manganese in Atlantic carbonate sediments. Geochim. Cosmochim. Acta 50, 1807-1818.

WEAST R. C. (1981) Handbook of Chemistry and Physics, 61st ed., CRC Press. 